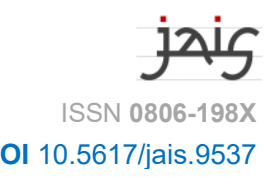

\title{
Beautiful vs. Ugly
}

\author{
By STEPHAN Guth
}

"How can you talk about a 'culture of beauty' (thaqāfat al-jamāl) while everything around us is ugliness (qubh)?" The elderly lady who raises her voice in the Q\&A session following one of the "Culture at the Frontline" (al-Thaqāfa fì 'l-muwäjaha) panel discussions at the Cairo International Book Fair in January/February after some distinguished gentlemen have made their learned statements about their view of the task of culture in present-day Egypt, is very upset. Full of anger, she reproaches the panelists, whom she obviously regards as representatives of the cultural (and political) establishment, blaming them of discussing lofty issues while neglecting people's basic needs [ 7 "The System" vs. "The People"] and of continuing to let cultural institutions such as public libraries decay: windows broken and not repaired, so that it is noisy and dust comes in and settles on everything; no proper catalogues; few holdings; the condition of the books deplorable... How can an average citizen make use of his right to education and get access to learning and culture under such circumstances?

Like the committed lady, most people perceive lived everyday realities as something rather ugly. And it is only natural that most of them also long for its corresponding opposite. Especially in the big cities [ $\nearrow$ Downtown/Centre-ville] with their noise, permanent traffic jams [ $\lambda$ Zahma], high levels of dirt and pollution [ $\lambda$ Garbage], the chaotic mushrooming of informal housing [ $\left.\lambda^{c} A s h w \bar{a}^{3} i y y \bar{a} t\right]$, the tristesse of uniform concrete or mud-brick architecture and the lack of parks or other areas set aside for public recreation, life is often experienced as a dehumanized "hell" (ABAZA 236). The longing for spaces where one could lead a life in dignity is exploited by big construction companies who invite those who can afford it [ $\nearrow$ Affluence $v_{s}$. Destitution] to buy themselves a new, beautiful home in a compound in one of the new desert cities that huge billboards along the roads or seductive TV spots and websites portray as the equivalent of "paradise" on Earth [ $\lambda$ Gated Communities / Compounds].

The - artificial — beauty of the gated communities is real—large parts of the big cities have come to consist of vast areas covered by luxurious compounds and chic trendy malls, and the 'paradisiacal' life in these places is regularly contrasted, in documentaries and fictional representations alike, with the chaos and dirt of the old city centres [ 7 Downtown/Centre-ville] as well as the miserable conditions in the poor slums [ $\left.\nearrow^{C} A s h w \bar{a} i_{i y y} \bar{a} t\right]$ (Nawwāra, The Nile Hilton Incident, Abadan lam nakun atfälan). Very often, however, these comments also are eager to underline that this beauty betrays; it is a false beauty, a surface only, behind which the truth of moral ugliness is concealed [ $\nearrow$ True vs. False]: the inhabitants of the beautiful villas are typically portrayed as criminals (corrupt, murderers), often closely associated with the regime (Nawwāra, The Nile Hilton Incident, Mawlānā, Fawqa mustawà al-shubuhāt). On the last day of the year, Wầil 'Abbās posts a cartoon on Facebook that shows, in a bird's eye panoramic view, a section of life in a metropolis: the city is divided into two parts by a high wall, with barbed wire on top; to the left, we see a crowded slum area, held in uniform grey, with houses like Nissen huts, covered by corrugated sheet roofs, some people standing on tiny balconies which they have to share 
with laundry and water barrels (obviously, the area is not connected to the communal water supply); in contrast, on the right half, covered by lush green meadow and trees, we see only one building, a villa with a swimming-pool, in front of which two people are relaxing on deck-chairs; one of them is saying to the other: "Praise to you, Lord, for the grace of living in such a safe, developed and humane place!" The cartoon had been part of the official advertising of the Beverly Hills Egypt compound in the new al-Shaykh Zāyid quarter. 'Abbās thinks that this sarcasm "tops the shit (il-kharā)" and deserves the prize for "the ugliest/worst ad (aswa' 'ilän) at the closing of 2016," and gets many supporting comments: "This is disgusting and would be illegal in most decent countries!!!," "What a dirty [lit., garbage-like] ad!," "That's pure filth (qadhära)!" (The photo was removed from the website the same evening!) (ABBAS).

Yet, people are longing for beauty, and wherever they have not come to terms with, or resigned to, the ugliness of their surroundings they are eager to counter it in some way or another. Flowers and colours play an important role. Munà Abāza tries to resist the declining sense for a nice environment (which she observes especially in the younger generation [ $\nearrow$ Young $v s$. Settled]) by cultivating flowers in the staircase of the multi-storey building she lives in in a Dokki neighbourhood (ABAZA 247). Village or suburb inhabitants welcome graffiti artists who paint the monotonous walls of their concrete or brick houses, shops, metro stations, or bus stops with colourful calligraphies, tags, vivid portraits or even wild "jolies fresques"- "Les stations de la banlieue sud de Tunis reprennent des couleurs," Kapitalis enthusiastically titles a report on the BeArt initiative (the name not only contains art but also plays on the Arabic word for 'environment', bla $a$ ) (Kapitalis, Aug.), and the tone is very similar when Egyptian media describe the activities of the Gedary (Arabic jidāri ' $m y$ walls') group who "teamed up with a group of Egyptian graffiti artists [to] give the village of Kafr El Ghab in Damietta [district] an indelible Eid present" by "adorn[ing it]s walls with 25 stunning pieces of graffiti" (CAIROSCENE, July); the rural commune embraces street art: "We wanted to beautify the town - to give it a certain feel, a certain flavour," explains a member of the municipal council; and it worked out, people were very responsive: "Something about its uncontrived language of colours and lines resonated with their pure unadulterated love for life when renowned graffiti artist Ahmed Gaber (alias A.K.A. Nemo) and his merry band of muralists adorned every street corner and every alley with graffiti." In the title of her article, the author of the report goes as far as praising "Graffiti as a Means of Development Across Egyptian Towns" (GHONEIM). The inhabitants of the Manshiyat Nāṣir district in Cairo, too, welcome the monumental, colourful calligraffito that Tunisian artist eL Seed paints over more than fifty of their houses, thus making aesthetics and colours triumph over the quarter's bleak mud brick architecture (DAWSON, EL SEED at TEDSummit, GALALAH)

Colours symbolize liveliness, vitality, and evidently they can give people back some of the dignity that tends to be lost in the uniformity, colourlessness and ugliness of everyday life. When the eleven-year-old daughter who grows up with a single mother in a Cairo slum and, though still a child, will soon have to marry an elderly man, puts on red nail polish (Abadan lam nakun atfălan); when the young cross-dressers in the documentary Travesties take great pains in dressing chic and colourful and making themselves up; or when the lower middle-class women from southern Tunisia who are portrayed in Les commerçantes dress in colourful clothes, all of them affirm for themselves their dignity as human beings, in spite of

jais • 21 (2021) - Themed Section In2016: *301-*313 
difficult living conditions (poverty, social marginalization, oppression, etc.). The longing for beauty within an otherwise ugly world is also behind the insistence, even in poor neighbourhoods (Abadan lam nakun atfälan), on extravagant furnishings for weddings and a brilliant appearance especially of the bride (Hārr jäff șayfan), where the whiteness of her dress also symbolizes immaculacy and purity, an aspect that often goes together with beauty.

A longing for beauty is obviously also behind the success of Egyptian photographer alManādīli who is eager to "tell the Egyptian[s] about the beauty of their city, which they (usually) do not see" (al-MANĀDİLİ, in Tahrīir/Tahrirnews), due to all its apparent ugliness. And he does so in an almost alienating manner: it is hard, for instance, to recognize the real, genuine Cairo in his photos of a clean, colourful, magically glittering Țal'at Harb square an early evening of a bright day with a clear, blue sky, immaculately white clouds, cleanrecently rain-washed? - and unusually empty streets, leading in geometric accuracy towards the square, where the statue of the 'father of Egyptian economy' [ $\lambda$ Father Figures] is dominated by the famous Ya'qūbiyān building, as if by a cathedral (ibid.).

Al-Manādîlī's success goes hand in hand with that of romance and romantic genres in general (JACQUEMOND), a success that is paralleled, on the other side of the spectrum, by the continued popularity of horror fiction - as if indulging in an even more ugly and terrifying imagined world could erase the ugliness and the fears of lived everyday reality—, and satire (where some kind of relief, if temporary, is brought about by laughing) [ $\lambda$ Inferiority = Superiority (Satire)]. The widespread longing for romance is fulfilled not only by all kinds of secular novels and soap operas, including a number of highly popular Ramaḍān series, but also by the Islamized varieties - cf., e.g., the continuing success of the 'Islamic' melodrama Fì qalbī unthà 'ibriyya (There is a Hebrew woman in my heart = HAMDĪ)—, in which the idea of the beauty of the well-arranged harmonious divine order of the world and the message of the Prophet find their expression in colourful book covers, often inspired by Nature (dawn, rainbows, landscapes, ...) and the physical and moral beauty of the protagonists [see also IIn Islam,...]. The same aesthetics can be observed in some of the Islamic pop singers' videos and the representation of televangelists like Muștafà HuUSNİ. Romance often also conveys optimism [ $\nearrow$ Hope vs. Hell], which, in ANDEEL's eyes, explains the striking success of the filmatization of Muhammad ȘĀDIQ's Hepta, a novel that, according to the critic, many classify as a piece of "teenage literature." Yet, although Andeel warns against the dangers of widespread unrealistic romanticizing tendencies, he still justifies the movie's success: in a world in which muhn, the distressing desire born out of sexual deprivation and nonfulfilment, can become a metaphor of everybody's desperate condition and longing for emotional fulfilment in life, a film that 'proves' that, indeed, "life is beautiful (lit., sweet, ilhayāh hilwa)" and encourages people to dare to fall in love, against all odds, serves an important task (ANDEEL, Arabic version).

In a similar vein, graffiti artist Nemo and his colleagues from the Gedary (Arabic jidārī 'my wall') initiative do not tire of underlining how essential it is already to surround children with beauty of all kinds: it will produce better human beings and thus also a better society and future (GHONEIM). With its humanist educational motivation, this initiative is closely related to many others that are driven by a wish to counter the squalors of 'barbarism' and the many dehumanizing aspects met in everyday life, including 'ugly' politics, by a more of culture in general. In their end-of-the-year review, the madàMașr team, for instance, reports 
that they tried, in the bygone year, to expand their culture section by including more contributions on design, literature, architecture, cinema, etc. (MADAMASSR).

They are not alone. In spite of, or perhaps also because of, the depressing, often dystopiainspiring political and economic situation $[\lambda$ Hope $=$ Hell $($ Dystopia) $]$ and the many obstacles and constraints that all work against a free unfolding of cultural activity [ $\lambda$ Freedom $v s$. Constraint], the year sees an unprecedented flourishing of promising fresh initiatives in many fields, all driven by a vision of maintaining culture, with all its facets, as a long-term necessity. In Egypt, Dalia CHAMS thinks the new activism that she observes in the cultural scene can be explained as a reaction of the alternative scene to the severe crackdown that this scene suffered after the regime had choked off promising postrevolutionary projects like al-Fann maydān (Art is a scene/place/square, ended 2014) and come down on highly productive, but also expressly or potentially oppositional institutions like the Cairo Townhouse or the adjacent Rawabet (Arabic rawābit 'links, connections') theatre, or on street art, where all kinds of experimental cultural expression had for some time found a space to unfold and develop and test out new concepts and approaches and give voice to alternative visions of a future political and social order (CHAMS) [ $\nearrow$ The Voice from Above]. True, the alternative scene has suffered heavy blows; but it could not be silenced: those active in it are now trying, perhaps more eagerly than ever, to maintain their activity and/or to establish new forms that, while still serving a re-humanizing purpose or the aim of upholding humanity in an increasingly 'barbarian' environment, are less susceptible to the regime's interference. In Cairo, the Zawya (Arabic zāwiya 'corner, angle') centre is able to organize a number of very popular events. Especially cinema can, it seems, to a certain degree serve as a "shelter from predominant thought" (CHAMS), if not even provide some "solace" (MADAMASSR) for the cultural activists who in many cases still live in a kind of limbo, in doubt whether they should dare to start a new project, or not knowing whether they will be able to continue an on-going one, always in danger of being attacked, arrested, detained, accused of offending public morals, or facing some other charge [ $\lambda$ Disappearances, $\lambda$ The Honourable Citizen, $\lambda$ Court Trials, $\lambda$ Hope $v$ s. Hell], and the projects into which they put much blood, sweat and tears may be stopped, forbidden, closed. Many consider emigration [ $\lambda$ Migration] because culture - the beautiful, colourful, pluralistic —is always also political, and if an initiative does not serve the regime's interests (as, for instance, beauty contests would do in Egypt) or the cause of 'our/true' Islam (in Tunisia) [ $\nearrow$ In Islam, ... ], all energy and emotional commitment that have gone into it run a high risk of having been invested in vain.

What makes the activists and advocates of beauty and culture take these risks and continue nevertheless, despite all obstacles, dangers, drawbacks, and constraints, are the many additional functions by which their projects surpass the purely aesthetical: A Footnote on Ballet History, an homage to the pioneering "Bolshoy Five" ballet dancers and the Egyptian prima ballerina, Magda Saleh (Mājda Șāliḥ), links the promotion of ballet dancing, once initiated by the great Gamal Abdel Nasser [ $\nearrow$ Father Figures], to national development and progress and to Egypt's forming part of the modern, civilized world in general. A good taste in the choice of the colours with which to paint the notorious barrels marking informal checkpoints [ $\left.\nearrow_{\mathrm{K} a \mathrm{~m} \overline{\mathrm{in}}]}\right]$ in a touristic region may help to make visitors feel more comfortable than the standard Red-White-Black of the Egyptian flag, locals claim in trying to convince

jais • 21 (2021) - Themed Section In2016: *301-*313 
the officials coming from the capital that the barrels should rather be painted in colours that are in harmony with the surrounding nature and the cultural character of the respective province (Sulaymān) [ $\lambda$ Center vs. Periphery]. Moreover, many cultural activists believe that promoting the beautiful and supporting art, literature, architecture, music, design, cinema, etc. helps develop that sense of creativity and inventiveness that is so much needed, if it is not indispensable for survival, under the present difficult economic circumstancestherefore the invention of a 'beautifully simple', "ingenious" app that looks as if it has the potential to solve a city's garbage problems [ $\nearrow$ Garbage, $\nearrow$ Mobile Phones] is nominated in CairoScene's retrospective on the year among the "16 of 2016," their shortlist of initiatives that have the potential of leaving a long-lasting imprint on Egypt and of "redesigning the country's human landscape" (Hosny \& Primo). In a similar vein, the transformation of old car tires into colourful garden chairs, tables and other furniture by a smart Egyptian from Mansoura receives enthusiastic acclaim and admiration in the press (Cairoscene, Feb.): here, beauty, made of something ugly — waste, garbage — , is instrumental in advancing techniques of $\pi$ Self-help. A photographer's fresh look on 'canonical' architectural highlights from several periods of history in the Tunisian capital not only underlines the beauty of the buildings themselves but also draws attention to the differences between historical epochs and their tastes, which can open one's eyes for the historical relativity and plurality of beauty (Younes) as well as for a continuity of fine taste that obviously could be maintained over the centuries and thus testifies to the high standing of Tunisian civilization that is on a par with other countries on an international level [ $\lambda$ Inferiority vs. Superiority]. The idea that, in essence, beauty remains the same while outward appearance may vary across time and changing tastes is also present in the " 100 Years of Egyptian Beauty" WatchCut video. "The looks we have chosen are very diverse in nature. Each represents various political struggles in each decade," explains Jacinthe Assaad, the researcher behind the video that shows one and the same woman in ten different attires, from the 1920 s to the 2010 s, inspired by 'typical' representatives of each decade, like the pioneer of women's emancipation, Hudà Sha'rāwī (1879-1947) for the 1920s, Princess Fawziyya Fu'ād (1921-2013) for the 1940s, a veiled woman for the 1980s (symbolizing beginning Islamist resistance against Sadat's Open Door politics and the influence of labour migration to the conservative Gulf states) (N. N.EgyptianStreets, Feb. 10). The video thus shows the historical relativity of varying expressions of beauty in close connection with political shifts and social change [ $\lambda$ Past vs. Present]. Similar to A Footnote on Ballet History, the Tunisian documentary Tahar Cheriaa: A l'ombre du baobab (In the baobab's shadow) is an homage to a pioneer of cultural activism: the 'father' of the Carthage Film Festival, Tahar Cheriaa (al-Ṭāhir Sharīa, 1927-2010) [ $\nearrow$ Father Figures]. It underlines the leading role Tunisian cultural activity once played for the whole so-called Third World, and the underlying message is: perhaps it can become such a pioneer again - if only politicians and society at large pay sufficient attention to the cultural sector and become more supportive again of the fine arts. The documentary We are Egyptian Armenians is eager to show how important an ethnic-religious minority like the Armenians has been for the development of the country. A sense of beauty and culture in general is mentioned here on an equal footing with smart entrepreneurship or a leading role in politics, so that singing ("Anouchka," born Wartanoush Garbis Slim, *1960), photography ("Van Leo," born Levon Alexander Boyadjian, 1921-2002), cartoon art ("Riḍà," creator of the well-

jais • 21 (2021) - Themed Section In2016: *301-*313 
known figure of the fat "Rufayya'a Hānim"), fine jewellery or sculpture are listed alongside the influential Armenian Nūbār Pasha (1825-99, the first Egyptian Prime Minister), tobacco merchants, or the producers of high-quality shoes or clocks, as equally relevant contributions to Egyptian cultural identity.

The organizers of the Festival de la lumière de Tunis in which parts of the Tunisian capital are illuminated in different colours during early autumn, emphasize that their project not only draws attention to architectural beauty tending to be overlooked in daily routine, but also that it casts new light, both literally and metaphorically, on known objects and thereby encourages the spectators, i.e., the people, to revalue their surroundings. With the help of "images fantastiques, réelles ou surréelles et d'une étrangeté tout aussi fascinante que troublante," they say, the project invites to re-explore old paths, question the seemingly given, and reflect on alternative ways of looking at the world - the first step to a culture of participation, tolerance, and democracy (La PRESSE).

The most important function of the aesthetic, however, seems to lie in the key role it can play both in searching and/or asserting (or re-asserting) one's identity. When the Tunisian cross-dressers of Travesties make up their faces, put on their party dresses and start dancing, the beauty of their make-up and attire and the elegance of their dancing also shows the beauty of their true self [ $\nearrow$ Dual Identities / Masking]. In 'Alà hallat 'aynī, the young female protagonist's music is not only a means of authentic self-expression while outside this world of music the girl leads another life, assimilated to what is expected of her, but it also serves the purpose of overcoming the trauma of detention and torture and helps her to reassert her identity: the first sounds Farah is capable of uttering after a long period of muteness consist of the melody of the patriotic but regime-critical song that she dared to sing in the bars before the secret police arrested her. - For the young theatre enthusiasts in the Tunisian documentary al-Hufra, pantomime fulfils, mutatis mutandis, a similar function: as long as they cannot afford to run their own theatre, the only way they can live in truth, as their true selves, is to live as pantomimes. - In contrast, both Jeanne d'Arc Masriya and Äkhir ayyām al-madīna do not so much describe art-particularly dancing and film-making — as a way of selfexpression or self-assertion; rather, they accompany the protagonists during their tentative searches for a true, authentic style. All the young women portrayed in Jeanne d'Arc have suffered trauma during the Revolution; now, they try to find a way back into normal life via an exploration of their selves [ $\lambda$ Self-help, $\lambda$ Psychiatrists] through dancing, sculpture, painting, metalwork, jewellery. In the documentary (which is interspersed with fictional elements), harmonious body movements and beautiful products of the women's art and handicraft are markers of the intricate beauty of their vulnerable souls, and the free human being in general, in all its delicate fragility. Ākhir ayyām follows a slightly different approach: It shows a protagonist who does not know yet where to go, whether to stay or to leave; Khālid is undecided whether he should find the Downtown Cairo surroundings with all its dirt and filth and poverty [ $\lambda$ Downtown/Centre-ville, $\lambda$ Garbage] ugly and repulsive, or whether there lies some - emotional, spiritual — beauty hidden in all this, some inner qualities that he could/should love and that would be beautiful enough to make him stay. In a similar vein, the "Iconic City" exhibition Cairo NOW! City Incomplete, shown at the Dubai Design Week, makes an attempt at a positive reassessment of what usually is regarded as ugly: taking the many incomplete buildings as its point of departure, it asks if there is not also an "aesthetics

jais • 21 (2021) - Themed Section In2016: *301-*313 
of incompletion." Rather than regarding the incomplete houses as ugly torsos, should we not acknowledge in them the 'beauty' of a realistic approach to the givens of difficult living conditions, economic crisis, etc., and is there not also an "unrealized potential" in these buildings that symbolizes something very positive: a strong belief in a future full of "possibilities waiting to be materialized"? (DUBAI DESIGN WEEK). - An extreme case of revaluation is the madàMașr team's appraisal of a 15-second video that goes viral in November, "spawning various spin-offs and," in the team's view, "somehow reflecting the year as a whole" (MADAMASTR, Dec.). The main 'event' in the video is a youngster's uttering the words for "fuck you" (kuss ummak) and "shit" (ahā) in front of the camera. While many comments on the YouTube page where the video is published (Kussummak kussummak), agree that this is absolutely disgusting, the madàMașr team regards it as one of "only a few shining moments" that "punctuated the gloom in Egypt's arts this year." They justify their vote by a 'thick description' that shows the fascination with a realism that comes close to the indulgence of dystopian fiction in cruelty, filth and decay as part of an 'aesthetics of the ugly' $[$ Hope $=$ Hell (Dystopia) $]$ :

In it, two young kids whisper in front of a camera on a balcony on a quiet afternoon. A tired grumpy father might be napping before a night shift, and a serious mother may be cooking with zero tolerance for kids' funny business. The kids do look like trouble even before they start doing anything. The smaller one is awed by the fact that the camera is recording a video. It's a life-changing moment. He asks twice: "Is that video!?" Then his expression shifts from innocent astonishment to pure lustful evil as he realizes the unlimited power he has just acquired by being able to freeze time and record whatever he can say. The energy leaks out of him to infect his brother/friend/partner-in-crime who stands behind and, knowing who his companion is, can already sense what's building. The friend starts dancing to an unheard beat, his body like a warrior filling with the ecstasy of imminent destruction, and the kid in the front, his eyes directly staring into the soul of whoever is watching, hisses (probably to make sure that the mother doesn't hear): "Fuck you... fuck you ... shit... shit..." (MADAMASTR, Dec.)

The search for new authentic ways of expression and adequate aesthetics that matches changed and still changing identities and attitudes towards a world that is one's own but in which one also feels increasingly alienated, is all the more complicated as it does not happen in a vacuum: beauty and culture are a highly contested terrain where free experimentation and (re-)interpretation of concepts and values is constantly impeded/obstructed by two powerful agents: the establishment (including the regime) and the neoliberal market which, especially if it aspires to be part of an international scene, "often reduces artists to stereotypical images of the country" (BOSKOVITCH). To find one's own, authentic style within the limits of what the regime allows, what the self-proclaimed defenders of public morality find acceptable, and what the market demands, on the one hand, and truthfulness to oneself is tantamount to walking a tightrope where you constantly are in danger of crashing. All forms of youth and popular culture, like rap or the so-called mahragānāt [ $\nearrow$ Pop Music], are easily discredited as 'low, inferior' forms of expression, too vulgar to compete with the 'timeless', classical music of Umm Kulthūm or 'Abd al-Wahhāb (al-Hufra) [ $\nearrow$ Young vs.

jais • 21 (2021) - Themed Section In2016: *301-*313 
Settled, $\nearrow^{6 T}$ The System" vs. "The People"]. Literature written in the vernacular, which has been booming ever since the Revolution [ $\nearrow$ Language] and is appreciated by many as being uncontrived, is considered 'ugly' by others who adhere to a traditional literary taste that would demand, for written and printed texts, the high register of Arabic, the fuṣhà.

The discussion that flares up in the media among literary critics in reaction to the Stockholm committee's granting Bob Dylan this year's Nobel Prize in Literature reveals that opinion is divided between supporters who praise the Committee's decision to include such forms of popular culture as is Dylan's music and lyrics, into their concept of 'literature' and, on the other side, voices that are highly critical of this decision, arguing that Dylan's texts lack that "effort on language" (jahd al-lugha) that is, and should remain, an indispensable criterion of good, high-quality literature and literary beauty (PEPE). In contrast, the supporters of a new, more inclusive aesthetics find it laudable and praiseworthy when books are written, or film stories told, "in a language they [i.e., the people] can grasp," as El Shimi has it in her comment on the success of this year's cinema blockbusters. - In contrast, the continued impact of traditional aesthetics makes it difficult for Muhammad Gābir, the inventor of a new Arabic type font, to convince sceptics of the advantages of his invention: practical utility and commercial potential notwithstanding, they regard this font as ugly, offending the beauty and quasi-"sanctity" of the traditional styles which, unlike the new one, all are capable of serving ornamental functions and have a longstanding calligraphy tradition (EL GIBALY). - However, being too commercial, sales-oriented, and perhaps also over-Westernized, is only one offence that products breaking with established aesthetics have to face. Adab, the Arabic term that usually translates the Western notion of 'literature, belles-lettres', is a word with a long conceptual history and can still also mean 'good manners, social graces, decency,' and a lack of it, qillat adab (vernacular: Pillit adab) denotes 'shamelessness, impudence, insolence, impertinence', sometimes even 'obscenity'. This is why an $\nearrow^{\prime}$ The Honourable Citizen' who thought that some passages in Ahmed Nagi (Aḥmad Nājī)'s novel Istikhdām al-hayāh with a rather explicit sexual content maliciously violated "the sanctity of morals and good manners ( hurmat al-ādāb al-'āmma wa-husn al-akhlāq)" and departed "from emotional modesty (khurūjan 'alà 'âtifat al-hayā')," could file a case against the author last year, and this is also why a North Cairo appeal court now can take up the earlier accusation of "the publication of written work that references transient lust and fleeting pleasure (shahwa fäniya wa-ladhdha $z \bar{a}^{\prime}$ ila)" (SAID) and sentence the 'culprit' to two years in prison although he had been acquitted in January (JACQUEMOND; MADAMASTR, Feb.; the sentence is again suspended in December, pending review; MADAMAST, Dec.) [ $\lambda$ Court Trials]. The establishment's - the "zombies-'," as Nagi himself calls them in his "Farewell to the youth" (Wadā'an lil-shabāb) message (JACQUEMOND) - verdict on any attempt that in their view has the potential of undermining the existing order, even if it stems from the pen of a representative of a narrow intellectual elite, here complements the Egyptian regime's crackdown on potentially subversive cultural institutions and its efforts to eradicate revolutionary graffiti in downtown Cairo [JDowntown/Centre-ville] - the murals, however beautiful they are, are too reminiscent of a "revolution of the people" ("Graffiti thawrat al-sha'b") that incited chaos. Jacquemond, a well-informed observer, thinks that the current powers' first enemy is not terrorism, as they usually claim, "but this rebellious youth that took to the streets in 2011, to whom Naji and his peers belong and give voice" [ $\nearrow$ Young vs. Settled]. Challenging

jais • 21 (2021) - Themed Section In2016: *301-*313 
established aesthetic norms and with them the hegemonic claims of the "paternalist, patriarchal and puritan" (Jacquemond), self-proclaimed "guardians of morality" (NAGI, apud SAID) is tantamount to questioning the legitimacy of the regime and, thus, rebellious insurrection [ $\nearrow$ Inferiority $\nu s$. Superiority].

Yet, while aesthetics often is highly contested, physical beauty as such, and female beauty in particular, seems to be more or less uncontroversial. Although beautiful celebrities, actresses of popular TV programs or protagonists of movies still look rather different from what a poll made by Superdrug finds out to be, for the Egyptians, the ideal bodies- - "the ideal male Egyptian will have a six pack, slightly dark skin, and thick dark hair" while for the ideal woman, "the results appeared to focus on the hips, legs and hair" (EGYPTIANSTREETS, Feb. 19) - , beautiful women regularly are made the bearers of beautiful ideas, particularly in cinematic fiction. For the filmatization of Hepta, Andeel observes (and criticizes) that the internal logic of the movie is still very much based on a male-dominated aesthetics [ 7 Male vs. Female]. But he also thinks that this can be tolerated as long as the overall message is beautiful - which, he thinks, is the case in Hepta because it encourages people to fall in love (ANDEEL). In other movies, fair, mostly young, women may embody a virtue like humanitarian self-sacrifice (the teen-age Muslim sister in Ishtibā $k$ who suppresses all feelings of shame and guilt to offend the prescriptions of Islamic law when she unveils to lend the needles of her niqā $b$ to a nurse who needs to fix a wound); or the unconditional love of a courageous mother who travels undercover to Syria, exposing herself to the danger of being killed, to find and rescue her son who has joined the ranks of jihadist fighters there (Zahrat Halab); or freedom, independence, true love and truthfulness (as represented by Rìm, the "Gazelle," in Hédi); or sensibility, empathy, understanding, openness towards the Other (as the two beautiful women protagonists in Corps étranger). Very often, however, this beauty is combined with trauma, fragility, or vulnerability: there is the beautiful singer-entertainer and high-class prostitute Gina who has suffered a lot from men and, in singing a song by Fayrūz, lets "her tears speak," her beauty and that of the music underlining her noble character (The Nile Hilton Incident; later in the film, she will be found dead, a victim of the criminal regime); there is 18-year-old singer Farah who becomes a veritable martyr of the freedom of expression when she is detained and tortured for nothing else but singing critical songs and who, towards the end of the movie, emerges from the experience as a broken person ('Alà hallat 'aynī; it is only in the very last scene that she is able to produce some sound again) (she is very much reminiscent of the huriyyat al-ta bir , an icon of the days of the Revolution in which female beauty - a hüriyya is one of the legendary virgins of Paradise, mentioned in the Qur'an - is combined, in a pun, with the Arabic term for 'freedom of expression', hurriyyat al-ta'bir); and there are the two protagonists of Ghadwa hayy who have suffered a traumatic experience during the days of the Revolution: when the boy together with whom they were hiding on the roof of a house was caught by two policemen, one of whom started to rape him [ $\nearrow$ The Policeman Criminal], they beat the rapist with an iron bar and left him almost dead; in this way, the initially innocent became guilty-veritable tragic heroines who, in the years following the Revolution, have tried hard, but never succeeded, to get past their trauma and guilt. In a move, it seems, of self-critical irony [ $\nearrow$ Inferiority $=$ Superiority (Satire)] and an attempt to avoid the clichés of mainstream cinema, the beautiful idea that a movie wants to convey may also be represented in the beauty

jais • 21 (2021) - Themed Section In2016: *301-*313 
of-a goat! In 'Alī Mi ${ }^{c} z a$ wa-Ibrāhìm, 'Alī's unconditional love for Nadà the Goat, with her snow-white fur that, like a bride's wedding dress, underlines her purity and innocence, seems to transcend human love due to the actual impossibility of the match, its 'madness'. Is a reference to the legendary lover Majnūn Laylà, the 'Madman of Layla', intended? We cannot know; but for 'Alī, Nadà-the-Goat is, as he declares to his friend, the spiritual experience of a pure soul ("Nadà bi'l-nisba lī rūḥ").

\section{Related Entries}

ARRAYS - 'Ashwä'iyyāt $\downarrow$ Court Trials $\downarrow$ Disappearances $\downarrow$ Downtown/Centre-ville $\downarrow$ Dual Identities / Masking $\downarrow$ Father Figures $\diamond$ Garbage $\downarrow$ Gated Communities / Compounds $\downarrow$ The Honourable Citizen $\downarrow$ In Islam, ... Kamin $\downarrow$ Language Migration Mobile Phones $\downarrow$ The Policeman Criminal $\downarrow$ Pop Music $($ mahragānāt $) \diamond$ Psychiatrists $\diamond$ Self-help $\diamond$ The Voice from Above $\diamond$ Zahma

CODES - Affluence vs. Destitution $\downarrow$ Center $v s$. Periphery $\downarrow$ Freedom vs. Constraint $\downarrow$ Hope vs. Hell Inferiority vs. Superiority Male vs. Female Past vs. Present "The System" vs. "The People" True vs. False $\diamond$ Young vs. Settled

CODES COLLAPSED - Hope $=$ Hell $($ Dystopia $) \diamond$ Inferiority $=$ Superiority $($ Satire $)$

\section{References}

\section{Written sources}

ABAZA, Mona (Munà Abāẓa). "Cairo: Personal Reflections on Enduring Daily Life.” JAIS, 16 (2016): 234-252.

ABBAS, Wael (Wā̉il 'Abbās). Facebook post of December 31, 2016, <https://www. facebook.com/ photo.php?fbid=10158096867675220\&set=a.10153039100570220.1073741829.523900219\&type=3>.

ABID, Zohra (Zuhra 'Abd). "Le Prix Comar du roman tunisien fête son $20^{\mathrm{e}}$ anniversaire." Kapitalis, March 24, 2016, <http://kapitalis.com/tunisie/2016/03/24/le-prix-comar-du-roman-tunisien-feteson-20e-anniversaire/> (as of April 24, 2016).

Agyad Multi Projects. "Live the Luxury Life at Agyad Garden City." [2016], <https:// www. agyadeg.com/> <http://www.agyadeg.com/projects/agyad-garden-city/>, <https://www.agyadeg com/ar/projects/agyad-garden-city/> (as of April 4, 2016, revisited April 6, 2018)

ALI, Amro. "Little by little, the dark seeds of the future Alexandria dystopia are planted in the present." Photo posted on Facebook, September 13, 2016, <https://www.facebook.com/photo. php?fbid=740878588255\&set=a.535912621695.2054993.204400427\&type=3\&theater $>$ (last accessed March 27, 2018).

ANDEEl (Andīl). "Hepta: Do you need to learn how to love?" madàMaṣr, April 29, 2016, <https:// www.madamasr.com/en/2016/04/29/feature/culture/hepta-do-you-need-to-learn-how-to-love/> (as of Apr. 29, 2016) / "Ḩībtā: Muhāạarat 'al-muhnn'." Ibid., May 3, <https://www.madamasr.com/ar/ 2016/05/03/feature/ثقافة/هيبتا-محاضرة-المخن/20, (as of Apr. 11, 2018).

AtTALAh, Lina (Līnā 'Ațā Allāh). "While a bad year for civil society all vow to find ways to continue." madàMaṣr, December 26, 2016, <https://www.madamasr.com/en/2016/12/26/ feature/ politics/while-a-bad-year-for-civil-society-all-vow-to-find-ways-to-continue/> (accessed March 25, 2018).

Boskovitch, Angela. "Artists imagine something else for Egypt (PHOTOS)." Your Middle East, February 18, 2016, <http:/www.yourmiddleeast.com/culture/artists-imagine-something-else-foregypts-art-scene-photos_38988> (last updated Feb. 18, 2016). 
Cairoscene Team [Feb.]. "Creative Mansoura Man Transforms Used Tires Into Eclectic Art." CairoScene, February 15, 2016, <http://www.cairoscene.com/ArtsAndCulture/CreativeMansoura-Man-Transforms-Used-Tires-Into-Eclectic-Art> (as of Feb. 15, 2016).

Cairoscene Team [Jul]. "Egyptian Art Initiative Adorns Damietta's Walls with 25 Stunning Pieces of Graffiti." Cairo Scene, July 10, 2016, <http://www.cairoscene.com/ArtsAndCulture/Egyptian-ArtInitiative-Adorns-Damietta-s-Walls-with-25-Stunning-Pieces-of-Graffiti $>$ (accessed March 25, 2018).

CHAms, Dalia. "Backed into a corner: Egypt's Independent Culture Five Years After the Revolution." ahramonline, January 26, 2016, <http://english.ahram.org.eg/News/185941.aspx> (as of Jan. 26, 2016).

DAwson, Aimee. "Q\&A with eL Seed: Changing perceptions." MadaMasr, April 1, 2016, <https:// www.madamasr.com/en/2016/04/01/feature/culture/qa-with-el-seed-changing-perceptions/> (last accessed March 11, 2018).

Dubai Design Week. "Iconic City: Cairo Now! City Incomplete, curated by Mohamed Elshahed.' Dubai Design Week, [n.d., 2016], <http://www.dubaidesignweek.ae/projects/iconic-city-caironow-city-incomplete/> (as of Oct. 24, 2016).

[EgyptianStreets, Feb. 10 =] N. N. "100 Years of Egyptian Beauty.” EgyptianStreets, February 10, 2016, <https://egyptianstreets.com/2016/02/10/100-years-of-egyptian-beauty/> (as of Feb. 10, 2016).

[EgyptianStreets, Feb. $19=$ ] N. N. "This Is What the 'Ideal' Man and Woman Looks Like in Egypt." EgyptianStreets - ES Buzz, February 19, 2016, <https://egyptianstreets.com/2016/02/19/this-iswhat-the-ideal-man-and-woman-looks-like-in-egypt/> (as of Feb. 19, 2016)

El GiBALY, Lara. "Completely horrific and painfully plausible: Mohamed Rabie's Otared." madàMașr June 24, 2016, <https:/www.madamasr.com/en/2016/06/24/feature/culture/completely-horrificand-painfully-plausible-mohamed-rabies-otared/> (as of July 10, 2016).

EL SEED at TEDSummit. "A project of peace painted across 50 buildings." Talk recorded June 2016 at TEDSummit, $<\mathrm{https}: / / \mathrm{www}$. ted.com/talks/el_seed_a_project_of_peace_painted_across_50_ buildings $>$.

[Freemuse $=$ ] N. N. "Egypt: Mahraganat artists challenge limits." Freemuse, February 23, 2016, $<$ https://freemuse.org/news/egypt-mahraganat-artists-challenge-limits/> (as of Feb. 23, 2016).

GalalaH, Kurt. "Tunisian Artist eL Seed Paints Manshiyat Naser With Stunning Graffiti." Scoop Empire, March 14, 2016, <https://scoopempire.com/tunisian-artist-el-seed-paints-manshiyat-naserstunning-graffiti/>.

GHoneIM, Niveen (Nīīn Ghunaym). "Gedary: Graffiti as a Means of Development Across Egyptian Towns." CairoScene, November 24, 2016, <http://www.cairoscene.com/ArtsAndCulture/GedaryGraffiti-as-a-Means-of-Development-Across-Egyptian-Towns> (accessed March 25, 2018).

El GiBALY, Lara (Lārā al-Jibālīi). "Hopes for an Arabic type boom: Breaking the rules but not too far." madàMașr, November 2, 2016, <https://www.madamasr.com/en/2016/11/02/feature/culture/ hopes-for-an-arabic-type-boom-breaking-the-rules-but-not-too-far/> (as of March 26, 2018).

"Graffiti thawrat al-shacb." Round-table discussion at the Cairo Book Fair (Q⿱土龰a'at al-mawā'id almustadīra), January 28, 2016.

Hosny, Farah, and Valentina Primo. "16 of 2016: The Egyptian Men and Women Changing the Country." CairoScene, December 30, 2016, <http://www.cairoscene.com/LifeStyle/16-of-2016Egypt-s-Real-Influencers>.

JACQUEMOND, Richard. "Ahmed Naji, the Use of Life and the zombies." madàMașr, February 23, 2016, $<$ http://www.madamasr.com/opinion/culture/ahmed-naji-use-life-and-zombies $>$ (as of Feb. 23, 2016).

jais • 21 (2021) - Themed Section In2016: *301-*313 
[Kapitalis $=$ ] N. N. "Les stations de la banlieue sud de Tunis reprennent des couleurs." Kapitalis, August 22, 2016, <http://kapitalis.com/tunisie/2016/08/22/les-stations-de-la-banlieue-sud-detunis-reprennent-des-couleurs/> (as of Aug. 22, 2016).

[madàMașr, Feb. =] N. N. "Appeals court sentences novelist Ahmed Naji to 2 years prison." Madà Mașr, February 20, 2016, <https://www.madamasr.com/en/2016/02/20/news/culture/appealscourt-sentences-novelist-ahmed-naji-to-2-years-prison/> (last accessed March 27, 2018).

[madàMașr, Dec. =] N. N. "Culture A-Z: Only a few shining moments punctuated the gloom in Egypt's arts this year." madàMașr, December 21, 2016, <https://www.madamasr.com/en/2016/ $12 / 21 /$ feature/culture/a-sad-dangerous-and-somewhat-dull-year-for-arts-in-egypt/> (last accessed March 26, 2018).

[madàMașr, Jan. =] N. N. "2016 in critical culture writing.” madàMașr, January 1, 2017, <https:// www.madamasr.com/en/2017/01/01/feature/culture/2016-in-critical-culture-writing/> (as of Jan. 1, 2017).

Metwali, Ati. "When the Going Gets Tough: On Challenges that 2016 Brought on Egypt's Cultural Scene." Ahram Online, December 25, 2016. <http://english.ahram.org.eg/NewsPrint/253846. aspx $>$ (accessed June 22, 2018).

PEPE, Teresa. "Dylan and the a-changing times of literature, in the Arab world and elsewhere." madàMașr, October 27, 2016, <https://www.madamasr.com/en/2016/10/27/feature/culture/dylanand-the-a-changing-times-of-literature-in-the-arab-world-and-elsewhere-2/> (as of Oct. 27, 2016).

[La Presse =] N. N. "Une édition attractive." 2016. La Presse (online), September 2, 2016, <http:// www.lapresse.tn/02092016/119420/une-edition-attractive.html> (as of Sept. 2, 2016).

RABĪ', Muhammad. 'Uțārid (Mercury). Cairo: Dār al-Tanwīr, 2015.

SAID, Omar ('Umar Sa'īd). "Trial of Ahmed Naji and editor begins for writing sexually explicit text." Madà Mașr, November 14, 2015, <https://www.madamasr.com/en/2015/11/14/news/culture/trialof-ahmed-naji-and-editor-begins-for-writing-sexually-explicit-text/> (last accessed March 27, 2018).

El SHIMI, Rowan (Rawān al-Shīmī). "A hopeful year for Egypt's cinema industry.” madàMașr, December 28, 2016, <https://www.madamasr.com/en/2016/12/28/feature/culture/a-hopeful-yearfor-egypts-cinema-industry/> (as of Dec. 28, 2016).

SULAYMĀN, Muḥammad al-Sayyid. "Tațīr madākhil al-Baḥr al-Aḥmar bi-dihān 'al-barāmīl' bi-alwān 'alam Mișr.” al-Mașrī al-yawm, October 13, 2016, <http://www.almasryalyoum.com/ news/details/1024085> (as of Oct. 13, 2016).

[al-Tahrī̄r/Tahrirnews =] N. N. "Shawāri' Miṣr bi-'adasat Ḥusām: qiș̣̦a yuwaththiquhā 'al-Manādīlì' fì șuwar." al-Tahrīir / Tahrirnews, March 25, 2016, <https://www.tahrirnews.com/posts/400839/>

“al-Thaqāfa fī 'l-muwājaha.” Podium discussion at Cairo Book Fair, Main Hall, January 29, 2016.

YounES, Najwa (Najwà Yūnus). "Tunis: Living History." Tunisia Live, February 26, 2016, <http:// www.tunisia-live.net/2016/02/26/tunis-living-history/> (as of Feb. 26, 2016).

\section{Movies}

Abadan lam nakun atfālan (We have never been kids). Documentary by Maḥmūd Sulaymān (Mahmood Soliman). Egypt, U.A.E., Qatar, Lebanon 2016.

Ākhir ayyām al-madina (In the last days of the city). By Tāmir al-Sa ${ }^{c} \overline{1}$ (Tamer el Said). Egypt, Germany, UK, U.A.E. 2016.

'Alà hallat 'aynī / À peine j'ouvre les yeux (As I open my eyes). By Leyla Bouzid. Tunisia, France, Belgium 2015*. 
'Alī Míza wa-Ibrāhīm (Ali, the Goat, and Ibrahim). By Sharīf al-Bandarī (Sherif El Bendary). Egypt, France 2016.

Un cercle autour d'une danse (A circle round a dance). Short film by Mouna Louhichi. Tunisia 2015*. Les commerçantes (The tradeswomen). Short film by Noussaiba Msallem. Tunisia 2015*.

Corps étranger (Foreign body). By Raja Amari. Tunisia, France 2016.

Fawqa mustawà al-shubuhāt. TV drama, written by 'Abd Allāh Ḥasan and Amīn Gamāl, Midhat al'Adl (ishrāf drāmī) and Muḥammad Rajā' (scenario), directed by Hānī Khalīfa. Egypt, Ramaḍān 2016.

A Footnote on Ballet History. Documentary by Hisham Abdel Khalek. Egypt, USA, France 2016.

Ghadwa hayy / Demain dès l'aube (Burning hope). By Luṭ̂i Āshūr (Lotfi Achour). Tunisia 2016.

Hārr jāff șayfan (Dry hot summers). Short film by Sharīf al-Bandarī (Sherif Elbendary). Egypt, Germany 2015*.

al-Hufra $\mid$ La fosse (The ditch). Short film by Achref Hammami. Tunisia 2016.

Ishtibāk (Clash). By Muhammad Diyāb (Mohamed Diab). Egypt, Germany, France 2016.

Jeanne d'Arc Masriya | Egyptian Jeanne d'Arc. Documentary Iman Kamel. Egypt, Germany, Kuwait, Qatar 2016.

Kussummak kussummak (Fuck your mother). YouTube video, posted by "Ahā Kānsir." October 26, 2016. $<$ https://www.youtube.com/watch?v=zo57B4ivgVc> (last watched Apr. 12, 2018).

Mawlānā (The Preacher). By Magdī Aḥmad 'Alī (Magdy Ahmed Ali). Egypt, U.A.E. 2016.

Nawwāra (Nawara). By Hāla Khalīl (Hala Khalil). Egypt 2016.

Nhibbik, Hād̄ / Hédi (Hedi). By Muḥammad Bin `Ațiyya (Mohamed Ben Attia). Tunisia, Belgium, France 2016.

Nihāyāt sa'̄ì (Happily Ever After). Documentary by Nadà Riyāḍ (Nada Riyadh) and Ayman al-Amīr (Ayman El Amir). Egypt 2016.

The Nile Hilton Incident. By Țāriq Șālih (Tarik Saleh). Egypt, Germany, Sweden, Denmark 2017**.

Shbābik al-janna / Les frontiers du ciel (Borders of heaven). By Fāris Nacnāc (Farès Naanaa). Tunisia, U.A.E. $2015 *$

Tahar Cheriaa: Taht zilāl al-bāwbāb/ A l'ombre du baobab (At the baobab's shadow). Documentary by Muhammad Shallūf (Mohamed Challouf). Tunisia 2015*.

Travesties. Short film by Safoin Ben Abdelali. Tunisia 2015*.

Zahrat Halab (The Flower of Aleppo). By Riḍa Bāhī (Ridha Behi). Tunisia 2016.

We are Egyptian Armenians. Documentary by Waheed Sobhi and Hanan Ezzat. Egypt 2016.

Yallah! Underground. Documentary by Farid Eslam. Egypt, Czechia, Germany, UK, Canada, USA 2015*.

* Produced in 2015 but shown in 2016 on national and international film festivals as still representative of the current situation and attitudes towards life.

** Published and shown on festivals in 2017 but shot in 2016. 